\title{
An Analisys Of The Heating Value Of Briquettes Made From A Mixture Of Rice Husk and Tea Dregs using Tapioca Adhesive
}

\section{Analisis Nilai Kalor Briket Berbahan Baku Campuran Sekam Padi dan Ampas Teh Menggunakan Perekat Tapioka}

\author{
Hendra Irawan ${ }^{1 *}$, Hendri Nurdin ${ }^{1}$, Ambiyar ${ }^{1}$, Rahmat Azis Nabawi ${ }^{1}$
}

\begin{abstract}
Increased energy consumption and lack of public knowledge to utilize rice husks and tea pulp as the most untapped briquette. The purpose of this research is to obtain a Calor value produced by rice husk briquette and tea pulp to be used as a briquette as an alternative fuel.. The results of the heat value test conducted using the Bomb calorimeter test tool showed optimum heat value in the variation of the $80 \%$ rice husk mixture and tea pulp and 20\% tapioca adhesive, the value of the resulting heat of 11,638,112 kj/kg. This shows that the rice husk briquette and tea pulp with a mixture of comparison of $80 \%$ mixture of raw materials with 20\% tapioca as higher glues produce a Calor value than 3 other variations. Based on the process that has been done shows that rice husk and tea pulp are potentially an alternative fuel.briquette and testing showed that rice husk and tea pulp could be potentially alternative fuel.
\end{abstract}

Keywords

Heating Value, Briquettes, Rice Husks, Tea Pulp, Tapioca

\begin{abstract}
Abstrak
Konsumsi energi yang semakin meningkat dan kurangnya pengetahuan masyarakat dalam memanfaatkan sekam padi dan ampas teh sebagai briket yang belum dimanfaatkan secara maksimal. Tujuan penelitian ini adalah untuk mendapatkan nilai kalor yang dihasilkan briket sekam padi dan ampas teh untuk dijadikan briket sebagai bahan bakar alternatif.. Hasil pengujian nilai kalor yang dilakukan mengunakan alat bomb calorimeter test menunjukan nilai kalor yang optimum pada variasi $80 \%$ campuran sekam padi dan ampas teh dan $20 \%$ perekat tapioka, nilai kalor yang dihasilkan sebesar $11638.112 \mathbf{~ k j} / \mathbf{k g}$. Hal ini menunjukan bahwa briket sekam padi dan ampas teh dengan perbandingan campuran $80 \%$ campuran bahan baku dengan 20\% tapioka sebagai perekatnya lebih tinggi menghasilkan nilai kalor dari 3 variasi lainnya. Berdasarkan proses yang telah dilakukan menunjukan bahwa sekam padi dan ampas teh berpotensi sebagai bahan bakar alternatif.
\end{abstract}

\section{Kata Kunci}

Nilai Kalor, Briket, Sekam Padi, Ampas Teh, Tapioka.

\footnotetext{
${ }^{1}$ Pendidikan Teknik Mesin, Universitas Negeri Padang

Fakultas Teknik, Kampus UNP Air Tawar, Jl. Prof. Dr. Hamka, Padang, Sumatera Barat. Kode Pos 25132

*hendrairawan0017@gmail.com

Submitted : February 10, 2020. Accepted : April 01, 2020. Published : May 01, 2020.
} 


\section{PENDAHULUAN}

Sumber energi yang banyak digunakan pada saat ini adalah energi tidak terbarukan yaitu energi yang berasal dari alam seperti minyak, batu bara dan gas alam, energi ini apabila digunakan secara terus-menerus akan habis. Merujuk pada kondisi yang terjadi, maka diperlukan adanya kebijakan energi yang harus dilakukan, antara lain dengan mendorong termanfaatkannya energi-energi secara lebih efisien dan tepat sasaran, serta meningkatkan teknologi dan ketersediaan informasi tentang energi alternatif secara lebih menyeluruh, serta menghemat pemakaian energi fosil dengan pemanfaatan energi terbarukan (Soelaiman, 2013). Di berbagai negara telah dilakukan Upaya konversi atau peralihan dari energi konvensional menjadi energi alternatif dan energi terbarukan. Salah satu upaya untuk menghindari ketergantungan energi yang dilakukan adalah pemanfaatan limbah pertanian, perkebunan dan kehutanan. Dimana penghasil limbah terbanyak berasal dari bidang pertanian (Lubis, 2018).

Energi biomassa dapat menjadi sumber energi alternatif pengganti bahan bakar fosil (minyak bumi) karena beberapa sifatnya yang menguntungkan yaitu dapat dimanfaatkan secara lestari karena sifatnya yang dapat diperbarui, relatif tidak mengandung sulfur sehingga tidak menyebabkan polusi udara, dan mampu meningkatkan efisiensi pemanfaatan sumber daya hutan dan pertanian (Ndraha, 2009). Umumnya bahan bakar biomassa memiliki densitas energi yang rendah. Untuk menghilangkan kelemahan ini maka sekam padi harus dijadikan briket. Bahan utama yang harus terdapat dalam bahan baku pembuatan biobriket adalah selulosa, semakin tinggi kandungan selulosa semakin baik kualitas briket. (Mahajoeno, 2005) Syarat briket yang baik adalah briket yang permukaannya halus dan tidak meninggalkan bekas hitam di tangan. Kompisicampuran, Aplikasi perekat, dan kehalusan baku mempengaruhi briket. (Nurdin, 2018) Pada penelitian (Jamilatun, 2008) nilai kalor briket sekam padi berkisar $3073 \mathrm{kal} / \mathrm{gr}$.

Karena briket dengan nilai kalor yang semakin tinggi menunjukkan karakteristik bahan bakar yang baik. Untuk itu perlu adanya inovasi seperti penambahan campuran bahan baku ampas teh. Limbah teh ini mudah diperoleh karena banyak terdapat di Indonesia sebagai negara yang luas akan perkebunan tehnya. Limbah teh yang dimanfaatkan berupa limbah padat yaitu ampas teh sisa dari setiap tahapan proses produksi penyeduhan teh. Nilai kalor briket dipengaruhi oleh perbandingan massa bahan baku dengan perekat, besaran partikel, gaya penekanan (kompaksi) (Nurdin, 2018). Penelitian ini bertujuan untuk mengetahui nilai kalor briket dengan menggunakan campuran perekat tepung tapioka dan getah damar, menentukan komposisi campuran yang paling optimal dan membandingkan nilai kalor briket bunga kelapa sawit menggunakan tepung tapioka dengan briket bunga kelapa sawit menggunakan getah damar.

Penelitian ini diharapakan mampu memanfaatkan potensi biomassa menjadi bahan bakar yang bernilai ekonomis bagi masyarakat. Berdasarkan kondisi bahan utama pembuatan briket seperti sekam padi dan ampas teh yang mudah didapat dan dijumpai disekitar kehidupan masyarakat. Penulis bermaksud melakukan penelitian mengenai uji nilai kalor briket sekam padi dan ampas teh, yang terfokus pada pembutan briket dan pengujian nilai kalor yang nantinya akan dijadikan bahan bakar dalam rangka pengembangan sumber energi alternatif pengganti bahan bakar fosil yang saat ini semakin menipis. Briket merupakan salah satu energi alternatif saat ini sebagai pengganti bahan bakar minyak. Semakin menipisnya bahan bakar fosil menjadi masalah besar dan tantangan kedepannya bagaimana menciptakan energi terbarukan yang dapat mengurangi konsumsi bahan bakar fosil. Briket merupakan sumber energi alternatif yang terbuat dari bahan bahan bekas atau bahan yang sudah tidak terpakai melalui pengolahan teknologi dan bisa digunakan sebagai bahan bakar alternatif pengganti minyak tanah dan elpiji (Yudha, 2018). 
Penelitian yang dilakukan merupakan penelitian eksperimen (experimental research) yang bertujuan untuk mengetahui pengaruh variasi perekat terhadap nilai kalor. Penelitian eksperimen adalah suatu metode penelitian yang digunakan dalam mencari pengaruh perlakuan tertentu terhadap yang lain dalam kondisi yang terkendalikan. Metode yang digunakan dalam pembuatan briket dengan membuat briket terlebih dahulu sebelum dilakukan pengujian.

\section{Pembuatan Briket Sekam Padi dan Ampas Teh}

Bahan baku pembuatan briket adalah sekam padi dan ampas teh. Bahan baku ini berupa biomassa yang didapat dari limbah penggilingan padi dan limbah teh setelah digunakan. Bahan baku didapat dengan cara di minta ke tempat penggilingan padi dan pedagang teh telur. Kemudian untuk sekam padi dijemur terlebih dahulu sebelum dilanjutkan pada proses penggilingan (Gambar 1 dan 2).

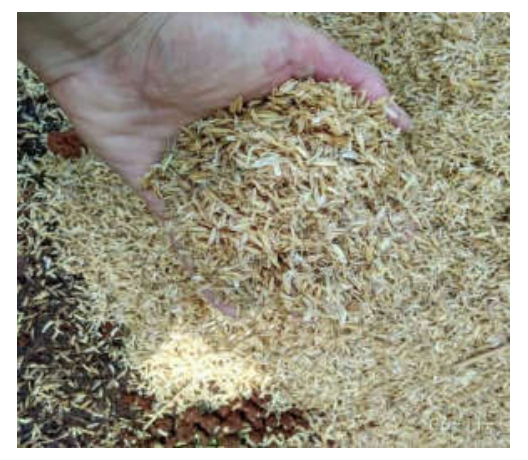

Gambar 1. Sekam padi

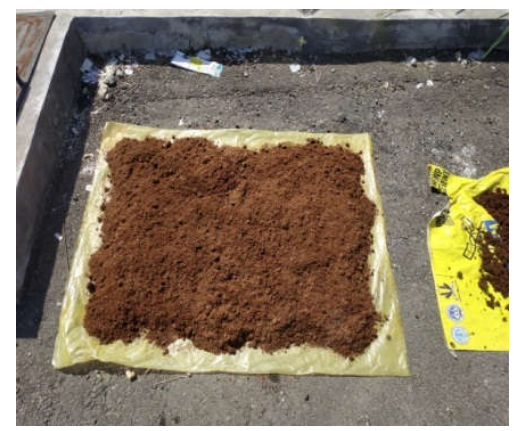

Gambar 2. Ampas Teh

Proses penggilingan bahan baku sekam padi yang sebelumnya telah dilakukan pengeringan dibawah sinar matahari untuk menghilangkan kadar air yang masih terkandung didalam seratnya. Kemudian sekam padi diperkecil ukurannya dengan cara menghaluskan menggunakan mesin dengan ukuran saringan $0,6 \mathrm{~mm}$, peroses penggilangan tersebut dilakukan dengan menggunakan mesin penggiling tepung/mixer. Peroses penggilingan dilakukan dilabor fenomena jurusan teknik mesin FT UNP

Dalam pembutan briket sekam padi dan ampas teh ini peneliti menggunakan tapioka sebagai perekat. Untuk persentase dari bahan baku dan perekat di gunakan 4 variasi yaitu: $90 \%$ : 10\%, 80\% : 20\%, 70\% : 30\%, 60\% : 40\% dengan sekam padi dan teh telah dicampur sama rata terlebih dahulu. Rincian variasi yang pertama 90\% campuran sekam padi dan ampas teh : 10\% perekat tapioka, variasi yang kedua 80\% campuran sekam padi dan ampas teh: 20\% perekat tapioka, variasi ketiga 70\% campuran sekam padi dan ampas teh : 30\% tapioka, dan variasi yang keempat $60 \%$ campuran sekam padi dan ampas teh: $40 \%$ tapioka. 
Setelah dialakukan persentase dari bahan baku, selanjutnya menentukan berapa gram berat bahan baku. Diketahui berat biobriket yaitu dengan tinggi $40 \mathrm{~mm}$, diameter luar $50 \mathrm{~mm}$ dan diameter lubang dalam $12 \mathrm{~mm}$. Dari ukuran briket tersebut diketahui berapa gram persentase variasi briket tersebut melalui formulasi sebagai berikut:

$$
\mathrm{BB}=\frac{\% \text { Variasi }}{100 \%} \times \mathrm{Bm}
$$

Keterangan :

$\mathrm{BB}=$ Berat Bahab Baku (Gram)

$\%$ Variasi = persentase yang di kehendaki

$\mathrm{Bm} \quad=$ Berat massa kering Briket

Pencetakan dilakukan dengan menggunakan mesin kempa/tekan (press mechines), yang di buat khusus untuk mencetak briket, selanjutnya masing masing variasi bahan dimasukkan kedalam cawan dicampur dengan air sebanyak $250 \mathrm{ml}$ lalu diaduk hingga merata dan dicetak menggunakan mesin kempa/tekan. Proses pencetakan dengan memasukkan sedikit demi sedikit kedalam nampan pencetak lakukan pengpressan hinggaa airnya hilang kemudian diamkan selam 2 menit. Setelah di press briket dikeluarkan dari alat pencetak lalu timbang massa basah briket. Selanjutnya briket di jemur dibawah sinar matahari sampai kadar airnya berkurang selama 4 hari, sampai briket benar-benar kering tidak memiliki kandungan air.

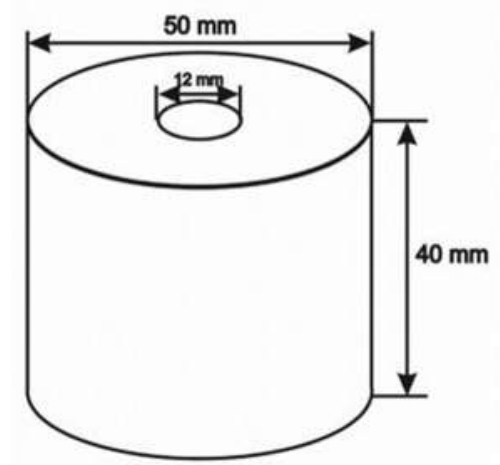

Gambar 3. Dimensi Pencetakan Briket Sekam Padi Dan Ampas Teh.

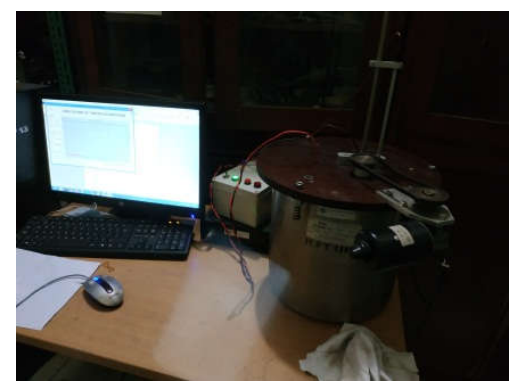

Gambar 4. Alat Bomb Calorimeter

Pengujian briket di mulai dari pengambilan sample uji seberat 0,2 gram, Kemudian sampel uji di masukkan ke mangkok uji, dan di letakkan pada tangkai pemegang kemudian pasang kawat pembakar sepanjang $10 \mathrm{~cm}$ yang berfungsi untuk membakar sampel uji yang ada dalam mangkok, selanjutnnya tangkai pembakar dimasukkan kedalam bomb calorimeter dan di tutup menggunakan baut penutup.selanjutnya tabung di beri oksigen sebesar $10 \mathrm{~kg} / \mathrm{cm}^{2}$, tabung bomb 
di masukkan kedalam bejana yang berisi air 2000ml kemudian pasangkan terminal pada tempat yang di sediakan di tabung bomb, kemudian tutuplah selubung mengunakan tutup selubung. nyalakan tombol pengaduk air yang berfungsi mengaduk air yang terdapat di dalam bejana air dan hidupkan termometer pengukur suhuair, pada komputer alat pengamat akan memperlihatkan garafik kenaikan suhu sebelum sampel terbakar sampai sesudah terjadi pembakaran.

\section{Teknik Analisis Data}

Instrumen yang dilakukan dalam penelitian ini adalah alat uji bomb kalorimeter. Pengujian menggunakan alat ini untuk mendapatkan selisih suhu awal dan suhu akhir pembakaran briket sekam padi dan ampas teh. Suhu maksimum yang dicapai briket arang pada saat pembakaran dapat dilihat melalui grafik suhu terhadap waktu. Data yang diperoleh dari masing-masing pengujian sampel ditabulasikan, selanjutnya untuk mendapatkan besarnya nilai kalor perlu dilakukan perhitungan menggunakan rumus:

$$
N b b=\frac{(H . \Delta T)}{m b b}(K J / K g)
$$

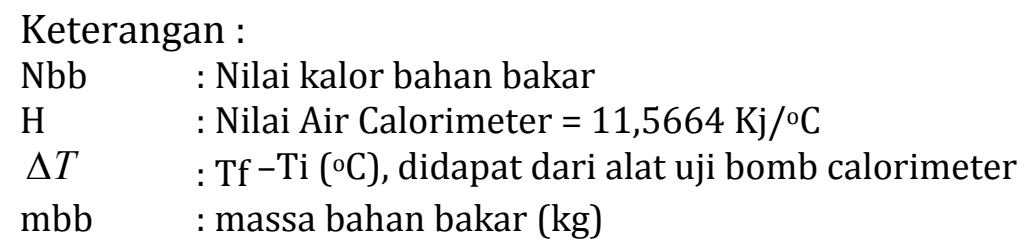

\section{HASIL DAN PEMBAHASAN}

Proses pembuatan briket harus memperhatikan beberapa hal yaitu peroses pengilingan harus mengunakan mesin penepung/mixer. Pencampuran sekam padi dan ampas teh dengan tapioka harus merata kemudian tambahkan air sebanyal $250 \mathrm{ml}$ kemudian dicetak dalam bentuk silinder yang sudah direncanakan. Variasi campuran yang dilakuan terdiri dari 4 variasi yaitu 1. (90\% campuran sekam padi dan ampas teh, 10\% tepung tapioka), 2.(80\% campuran sekam padi dan ampas teh, 20\% tapioka), 3.(70\% campuran sekam padi dan ampas teh, 30\% tapioka), 4.(60 campuran sekam padi dan ampas teh, 40\% tapioka). Variasi yang telah dilakukan bertujuan untuk mencari nilai kalor optimum dan minimum dengan melakukan uji nilai kalor briket sekam padi dan ampas teh.

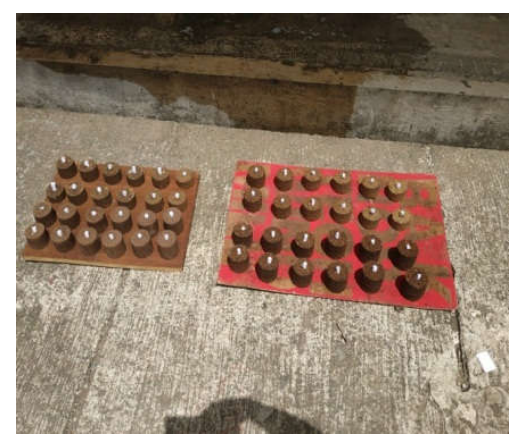

Gambar 5. Briket Campuran Sekam Padi dan Ampas Teh

Hasil pengujian nilai kalor yang dilakukan mengunakan alat bomb calorimeter test menunjukan nilai kalor yang optimum pada variasi $80 \%$ campuran sekam padi dan ampas teh dan 20\% perekat tapioka, nilai kalor yang dihasilkan sebesar $11638.112 \mathrm{kj} / \mathrm{kg}$. Hal ini menunjukan bahwa briket sekam padi dan ampas teh dengan variasi campuran $80 \%$ campuran 
sekam padi dan ampas teh dengan 20\% tapioka sebagai perekatnya lebih tinggi menghasilkan nilai kalor dari 3 variasi lainnya, maka variasi $80 \%$ : 20\% direkomendasikan sebagai perbandingan campuran yang baik dalam pembuatan briket sekam padi dan ampas teh.

Setelah melakukan penelitian ada beberapa hal yang telah dicapai dan didapat serta dapat dipahami seperti mempersiapkan dan merencanakan penelitian yang meliputi penyediaan alat dan bahan, proses penggilingan bahan baku, proses pengeringan bahan baku, proses menetukan variasi campuran (menimbang berat bahan baku yang akan di variasikan), proses pembuatan briket, proses pengujian nilai kalor dan penulisan laporan. Dalam penelitian ini telah dibuat briket dengan bahan baku dasar sekam padi dan ampas teh.

Proses pembuatan briket sekam padi dan ampas teh dilakukan dengan menentukan variasi campuran (menimbang dan menghitung bahan baku yang akan digunakan). Perbandingan jumlah campuran yang dibuat 4 variasi yaitu: $90 \%$ : 10\%, 80\% : 20\%, 70\% : 30\%, 60\% : 40\%. Briket yang dicetak berbentuk silinder dengan diameter $50 \mathrm{~mm}$ yang pada bagian tengahnya berlubang $12 \mathrm{~mm}$ dan tingginya $40 \mathrm{~mm}$. Pencetakan dilakukan dengan tekanan, dan peroses terakhir yaitu pengeringan briket dibawah sinar matahari selama 4 hari.

Briket yang telah kering digunakan sebagai sampel uji. Pengambilan 5 sampel setiap variasi dibutuhkan sehinggah memudahkan dalam pengujian nilai kalor. Pengujian nilai kalor briket yang dilakukan dengan menggunakan alat boomb kalorimeter oxy 360 untuk melihat nilai kalor briket sekam padi dan ampas teh.Hasil pengujian dan analisis data uji yang dilakukan diperlihatkan pada Tabel 1.

Tabel 2. Hasil dan data uji nilai kalor briket sekam padi dan ampas the dengan perekat tapioka

\begin{tabular}{|c|c|c|c|c|c|}
\hline \multicolumn{4}{|c|}{ komposisi persentase } & massa & massa \\
basah & nering & nilai kalor \\
\hline $\begin{array}{c}\text { sekam padi } \\
(\%)\end{array}$ & $\begin{array}{c}\text { ampas teh } \\
(\%)\end{array}$ & $\begin{array}{c}\text { tapioka } \\
(\%)\end{array}$ & $(\mathrm{gr})$ & $(\mathrm{gr})$ & $(\mathrm{kj} / \mathrm{kg})$ \\
\hline 45 & 45 & 10 & 78,6 & 51,8 & 6939,840 \\
\hline 40 & 40 & 20 & 83,6 & 55,6 & 11638,112 \\
\hline 35 & 35 & 30 & 92 & 63,8 & 9681,007 \\
\hline 30 & 30 & 40 & 105,8 & 70,4 & 7973,876 \\
\hline
\end{tabular}

Nilai kalor tertinggi briket sekam padi dan ampas teh dengan menggunakan campuran tepung tapioka diperoleh pada variasi $80 \%$ campuran sekam padi dan ampas teh dengan $20 \%$ perekat tepung tapioka dengan rata-rata nilai kalor $11638.112 \mathrm{~kJ} / \mathrm{kg}$. Variasi $70 \%$ campuran sekam padi dan ampas teh dengan 30\% perekat tepung tapioka dengan rata-rata nilai kalor $9681.007 \mathrm{~kJ} / \mathrm{kg}$. Variasi 90\% campuran sekam padi dan ampas teh dengan $10 \%$ perekat tepung tapioka dengan rata-rata nilai kalor $7973.876 \mathrm{~kJ} / \mathrm{kg}$. Variasi $60 \%$ campuran sekam padi dan ampas teh dengan $40 \%$ perekat tepung tapioka memperoleh nilai kalor terendah dengan ratarata nilai kalor $6939.840 \mathrm{~kJ} / \mathrm{kg}$.

Nilai kalor briket berpengaruh terhadap kualitas briket. Semakin tinggi nilai kalor suatu briket maka semakin baik pula kualitas briket yang dihasilkan. Dari data penelitian menunnjukkan bahwa komposisi campuran $80 \%$ campuran sekam padi dan ampas teh dengan $20 \%$ perekat tepung tapioka memiliki nilai kalor tertinggi. Nilai kalor akan mengalami penurunan jika melebihi batas nilai pencampuran perekat. Hal ini disebabkan oleh kadar air yang terlalu tinggi, sehingga menyebabkan nilai kalor akan mengalami penurunan (Amin, A.Z, dkk, 2017).

Perbedaan nilai kalor briket sekam padi dan ampas teh perekat tapioka dengan jelas dapat lihat pada grafik hasil pengujian pada Gambar 


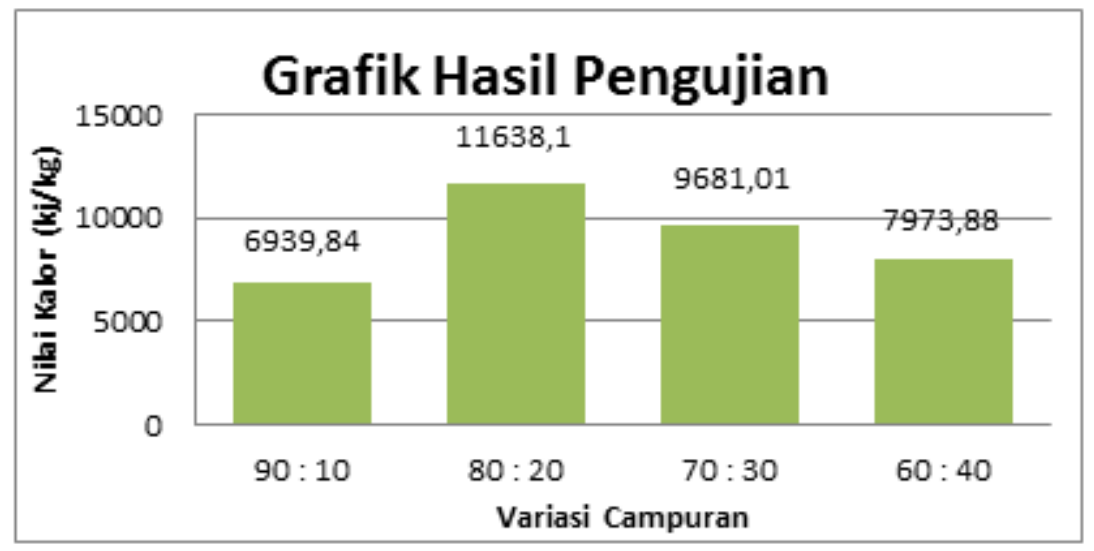

Gambar 6. Grafik Hasil Pengujian

Pada gambar menunjukkan nilai kalor briket sekam padi dan ampas teh diantara 4 variasi campuran. Variasi $80 \%$ campuran sekam padi dan ampas teh $20 \%$ tepung tapioka menghasikan nilai kalor sebesar $\mathbf{1 1 6 3 8 . 1 1 2} \mathbf{~ k j / k g ~ d a n ~ n i l a i ~ k a l o r ~ t e r e n d a h ~ b r i k e t ~ c a m p u r a n ~ s e k a m ~ p a d i ~ d a n ~}$ ampas teh dengan perekat tapioka pada variasi $90 \%$ campuran sekam padi dan ampas teh 10\% tepung tapioka menghasilkan nilai kalor sebesar $6939.840 \mathrm{kj} / \mathrm{kg}$.

\section{SIMPULAN DAN SARAN}

\section{Simpulan}

Hasil uji nilai kalor briket sekam padi dan ampas teh dengan menggunakan perekat tepung tapioka setelah dilakukan pengujian sebanyak 5 kali diperoleh nilai kalor pada variasi campuran $90 \%$ campuran sekam padi dan ampas teh dengan 10\% perekat tepung tapioka diperoleh rata-rata nilai kalor sebesar $6.939,840 \mathrm{~kJ} / \mathrm{Kg}$, variasi campuran $80 \%$ campuran sekam padi dan ampas teh dengan 20\% perekat tepung tapioka diperoleh rata-rata nilai kalor sebesar $\mathbf{1 1 . 6 3 8 , 1 1 2} \mathbf{~ k J / K g}$, variasi campuran 70\% campuran sekam padi dan ampas teh dengan 30\% perekat tepung tapioka diperoleh rata-rata nilai kalor sebesar $\mathbf{9 . 6 8 1 , 0 0 7} \mathbf{~ k J / K g}$ dan variasi campuran $60 \%$ campuran sekam padi dan ampas teh dengan $40 \%$ perekat tepung tapioka diperoleh nilai kalor rata-rata $7.973,876 \mathrm{~kJ} / \mathrm{Kg}$.

Hasil pengujian briket sekam padi dan ampas teh dengan menggunakan perekat tepung tapioka didapati bahwa komposisi campuran 80\% sekam padi dan ampas teh dengan $20 \%$ perekat tepung tapioka merupakan komposisi campuran yang paling optimal. Perbandingan massa bahan baku briket dengan perekat mempengaruhi besarnya nilai kalor. Jika terlalu banyak mencampurkan perekat dapat menurunkan nilai kalor, begitu juga sebaliknya. Jadi, dalam dalam pembuatan briket perbandingan massa bahan baku dengan perekat harus diperhatikan.

\section{Saran}

Penelitian selanjutnya diharapkan mampu menemukan bahan baku berupa limbah yang memiliki nilai kalor yang tinggi agar dapat menghasilkan briket yang lebih potensial untuk dijadikan bahan bakar alternatif. Pemerintah harus berperan aktif dalam menangani limbah, khususnya limbah pertanian yang berpotensi menjadi bahan bakar alternatif. Untuk penelitian selanjutnya disarankan untuk melakukan perlakuan karbonisasi agar dapat meningkatkan nilai kalor yang lebih tinggi. Untuk penelitian berikutnya disarankan melakukan pengujiaan karakteristik briket yang lainnya seperti kadar abu, kadar air, kerapatan 


\section{DAFTAR RUJUKAN}

[1] Amin, A. Z, Pramono, P., \& Sunyoto, S. (2017). Pengaruh Variasi Jumlah Perekat Tepung Tapioka terhadap Karakteristik Briket Arang Tempurung Kelapa. Sainteknol: Jurnal Sains dan Teknologi, 15(2), 111-118.

[2] Asri Saleh.2013. "Terhadap Nilai Kalor Pembakaran Pada Biobriket Batang Jagung (Zea May Efisiensi Konsentrasi Perekat Tepung Tapioka L)”. Jurnal Teknosains. (vol 7 no.1, hal 78).

[3] Buku Pedoman Penulisan Karya Ilmiah Skripsi/Tugas Akhir dan Proyek Akhir. (2014). Padang: FT UNP.

[4] Eka Jati, Bambang Murdaka dan Tri Kuntoro Priyambodo. 2008. Fisika Dasar. Jakarta: Andi.

[5] Ghani, muhammad A. 2002. Buku Pintar Mandor Dasar-Dasar Budi Daya Teh. Jakarta: Penebar Swadaya

[6] Jamilatun S. 2008. Sifat-sifat penyalaan dan pembakaran briket biomassa, briket batu bara dan arang kayu . Jurnal Rekayasa Proses.2(2):39-40.

[7] K.D. Maidison. (2006). Briket Batubara Sebagai Alternatif Pengganti Minyak Tanah.Bandung.http://www.Indeni.org

[8] Lubis, K., 20018. Tranformasi mikropori ke mesopori cangkang kelapa sawit terhadap nilai kalor bakar briket arang cangkang kelapa sawit. Pasca Sarjana, Universitas Sumatra Utara. Medan.

[9] Mahajoeno. (2005). Energi Alternatif Pengganti BBM : Potensi Limbah Biomassa sawit Sebagai Sumber Energi Terbarukan. http://www,ipard,com. Artikel. Diakses 28 Februaru 2019

[10] Ndraha N.2009. Uji Komposisi Bahan Pembuatan Briket Bioarang Tempurung Kelapa dan Serbuk Kayu Terhadap Mutu yang Dihasilkan.Sumatra Utara:USU.

[11] Prasad, C.S., Maiti, K.N., and Venugopal R.,2001. Effect of rice husk ash in white ware compositions. Ceramic Internasional, 27, 629-635.

[12] Soelaiman, R.J., 2013. Perbandingan karakteristik antara briket-briket berbahan dasar sekam padi sebagai energi terbarukan. Jurusan Fisika. Fakultas Matematika Dan Ilmu Pengetahuan Alam. Iniversitas Jember, Jember.

[13] Sulisyanto A. (2006). Karakteristik Pembakaran Biobriket Campuran Batubara dan Sabut Kelapa, Vol 7, No.2, pp 77-84.

[14] Surono. 2010. Peningkatan Kualitas Pembakaran Biomassa Limbah Jagung sebagai Bahan Bakar Alternatif dengan Karbonisasi dan Pembriketan. Skripsi. Universitas Janabadra Yogyakarta.

[15] United Nasional Environment Programme.(2006). Bahan Bakar dan Pembakaran www.energyfficiencyasia.org UNEP 23

[16] Yudha, Setiadi. 2018. "Pengaruh Penggunaan Perekat Tapioka Dan Perekat Damar Terhadap Nilai Kalor Bahanbakar Biobriket Tebu Tibarau".Skripsi.UNP. 